\title{
Comparison between Mixtures of Asphalt with Palm Oil Shells and Coconut Shells as Additives
}

\author{
(Perbandingan antara Campuran Asfalt dengan Tempurung Kelapa Sawit dan \\ Tempurung Kelapa sebagai Bahan Tambahan) \\ Ramez A. Al-Mansob, Amiruddin Ismail*, Mohammed A. Algorafi, \\ Mohammad Hesam Hafezi \& Mojtaba Shojaei Baghini
}

\begin{abstract}
The finding of other alternative material that has become the concern of various works lies in the fact that the material is to serve as an additive in asphalt mixes to enhance its physical properties. This paper deals with a laboratory study which compares the performance of hot mix asphalt (HMA) with the use of palm oil shells (POS), also with coconut shells (CS) as an additive and control samples. Both the palm oil shells and coconut shells are put in separately, taking up the shape of coarse aggregate with the size of $4.75 \mathrm{~mm}$. The amount of these palm oil shells and coconut shells blended into the mixes is expressed in respective percentage $(0,5,10,15$ and $20 \%)$ of the total weight of the size $4.75 \mathrm{~mm}$ of aggregate. The Superpave method was employed to design the mixes. Samples were prepared and put to the test for the rutting characteristic as the indicator to the performance examined. It was observed that the addition of the coconut shells has made the HMA better with respect to their resilient modulus under $40^{\circ} \mathrm{C}$ of temperature, it is cleared that $20 \%$ of CS as additive is the best percentage in term of resilient modulus among the percentages that have been chosen. However, it is contrary for the POS. The POS and CS addition will lead to that the asphalt concrete becoming more responsive to permanent deformation (static and dynamic creep) for more than 5\% of shells content. In general, the CS emerges as better additives than POS in the HMA.
\end{abstract}

Keywords: Palm oil shell; coconut shell; creep; resilient modulus; asphalt mixtures

ABSTRAK

Penemuan bahan alternative lain yang telah menjadi keprihatinan pelbagai kerja, terletak pada hakikat bahawa bahan ini adalah digunakan sebagai bahan tambah dalam asphalt campuran untuk meningkatkan sifat-sifat fizikalnya. Kertas ini membincangkan satu kajian makmal yang membandingkan prestasi asphalt campuran panas (HMA) dengan menggunakan tempurung kelapa sawit(POS) dan tempurung kelapa(CS) sebagai bahan tambah dengan sampel kawalan. Kedua-dua POS dan CS yang dimasukkan secara berasingan, mengambil tempat agregat kasar yang bersaiz $4.75 \mathrm{~mm}$. Jumlah POS dan CS ini kemudiannya dicampur ke dalam campuran masing-masing dalam peratusan $(0,5,10,15$ dan 20\%) daripada jumlah beratagregat berasaiz $4.75 \mathrm{~mm}$. Kaedah Superpave telah digunakan untuk rekabentuk campuran. Sampel telah disediakan dan diuji untuk ciri-ciri pengeluman sebagai penunjuk kepada prestasi yang diperiksa. Didapati bahawa, penambahan CS telah menghasilkan HMA yang baik bagi modulus kebingkasan di bawah suhu $40^{\circ} \mathrm{C}$, ia menunjukkan bahawa $20 \%$ CS sebagai bahan tambah adalah peratusan yang terbaik di antara peratusan yang dipilih bagi modulus kebingkasan. Penambahan POS dan CS akan menyebabkan konkrit asphalt lebih responsive kepada perubahan bentuk tetap (rayapan static dan dinamik) bagi kandungan CS yang melebihi 5\%. Secara keseluruhannya CS muncul sebagai bahan tambah yang lebih baik berbanding POS dalam HMA.

Kata kunci: Tempurung kelapa sawit; tempurung kelapa; rayapan; modulus kebingkasan; campuran asfalt

\section{INTRODUCTION}

Many studies have confirmed the fact that a lot of waste materials (ash, scrap tire, iron and steel slag, fly ash, and plastic waste) can make some good improved materials for pavement construction (Basri et al. 1999; Huang et al. 2007; Olanipekun et al. 2006; Shafigh et al. 2011). The expensive disposal of waste material can well be mitigated by way of having it added to the asphalt mixture or road pavement.

Existing waste materials can generally be divided into four sub-categories, namely: industrial, domestic, mineral, and agricultural. With several factors coming into play, like time and changes and technological advancements, it is likely that some of these materials be withdrawn from 
the production, while new types will surface and are actively used. According to Chen et al. 2002; Ferguson et al. 1995; Shen et al. 2000 and Smallwood 2000, construction waste is becoming a serious environmental problem in many large cities in the world. Fishbein 2008 study shown that construction and demolition debris frequently make up 10 to $30 \%$ of the waste received at many landfill sites around the world.

Palm oil shell (POS) and coconut shell (CS) have hardly been popular ingredients in asphalt mixture but instead, they are often regarded and treated as agricultural wastes. Palm oil and coconut processing, respectively, are obtainable in abundance in the part of the world where the climate is largely tropical; Asia, Africa, and America are some examples.

Nowadays, POS and CS application as additives in hot mix asphalt is non-existent. This is down to the scarcity of researches being conducted in of the evaluation of the great possibility of both POS and CS as an alternative material for more robust performance of asphalt mixes, specially tailored to the Malaysian condition.

Many studies have established the use of palm oil shell as the source of phenol. The use of palm oil shell applies as lightweight aggregate in structural concrete and as energy source (Teo et al. 2006; Mannan et al. 2006; Teo et al. 2007). Palm oil shells had been useful for the manufacturing of Bio-oil and for the production of activated carbon by pyrolysis and steam activation in a fixed bed reactor (Vitidsant et al. 1999). The expansion of this practice whereby it is confirmed to be a potential measure for having economical and improved performance of new flexible pavements as compared to the typical hot mix asphalt (Muniandy \& Huat 2006).Pavement damage can become the nastiest and not a pretty sight especially in Malaysia where the climate is hot (Kordi et al. 2010).

The progress of modified asphalt mixes has been highlighted over the past decades to fulfill the aim of improving the performance shown by the pavements mixes. To add, it is essential to exploit the vast quantity of POS as the world's second largest producer of palm oil is Malaysia, as in 2012, which produced about 18.900 million tons of palm oil and produced more than 577 thousand tons in 2011 (Chandramohan 2002; FOASTAT 2011; Pakiam 2013; Shean 2012).

This study was aimed to look into the effect of adding POS and CS on the characteristics of hot mix asphalt where its volumetric properties are concerned, and then ascertain the optimum bitumen content that contributes the most to the improvement of the modified hot mix asphalt mixes; assess the mixes by running a test for the resilient modulus and creeps; and comparing all results between the POS, CS and control mixes. Hence, there is an urgency to embark on a detailed study on Malaysian hot mix asphalt (HMA) performance using the modifying agents of POS and CS (Laili 2009).

\section{EXPERIMENTAL DESIGN}

There are several laboratory tests conducted as to meet the objectives of the study.

\section{MATERIALS}

Two types of mixes had been innovated with the certain percentage by weight of additives namely palm oil shells (POS) and coconut shells and the control mix without additives. The procedures adopted for the laboratory works were referred to the American Society for Testing and Material (ASTM) specifications guided by the Superpave design procedures and to American Association of State Highway and Transportation Officials (AASHTO) (ASTM International 1990; AASHTO 1994).

\section{METHODOLOGY}

The laboratory works involved several stages that start with the aggregates preparation and distribution into various particle sizes via the sieve analyses. The first stage sees the quarry aggregates being sieved in dry condition and blended, at the same time meeting the gradation limit that meets the ASTM specification. The washed-sieve analysis was referred to ASTM C 117 in order to ascertain the composition of mineral filler content needed in the aggregates gradation. The determination of specific gravity for both coarse and fine aggregates had been performed following the standards of both ASTM C 127 and C 128 (ASTM 2003a; ASTM 2003b).

For this study, the aggregate-form POS and CS were added where the size was recorded to be $4.75 \mathrm{~mm}$. The amount of each POS and CS additives added to the mixes was given in percentage $(0,5,10,15$ and $20 \%)$ of the total weight of size $4.75 \mathrm{~mm}$ of the aggregate. The second stage lies in performing the samples for both mix designs of the POS and CS. The bulk specific gravity and density of the compacted sample were performed adhering to ASTM D2726 (ASTM 2010). However, the compacting method was referred to Superpave method (Asi 2007; Memon 2006). The Resilient modulus, static and dynamic creep tests were conducted for compacted samples using the IPC Global Universal Testing Machine. An average value of the theoretical maximum density was derived from the test as described in ASTM D 2041 on two samples for each different mixes (ASTM 2010). $80 / 100$ penetration asphalt cement was employed in this research.

From the result gained from the study, the performance of different mixes with a range of percentage of POS and CS added are obtainable. Then, samples that qualify as giving the best performances were determined by having the values suggested 
compared, according to the specifications outlined by the ASTM. If the mixes' performance was found to be impacted by the addition of POS and CS, the optimum content of POS and CS that improve the characteristics of HMA mixes the most, was determined. Then a comparison between the results of each the shell-type will be done to know which additives is deemed more appropriate and receives more effect.

\section{RESULTS AND DISCUSSIONS}

Based on the ASTM D 3515-96 (D-4), the aggregates were blended as in Figure 1, and sieved (ASTM 1996). Aggregates were batched based on the passing percentage on size of the sieve.

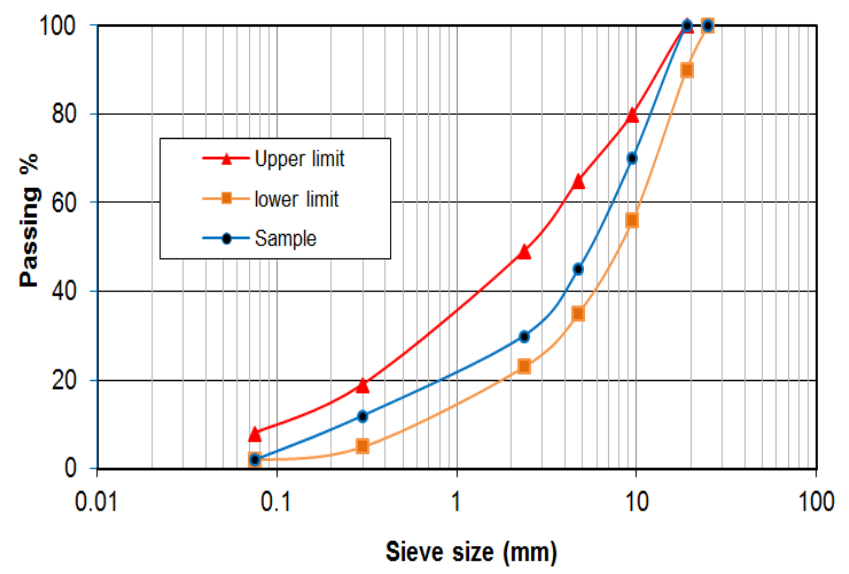

FIGURE 1. Limits of aggregates gradations and gradation used (ASTM D3515)

The specific gravity analysis of aggregates and shells was according to ASTM C 127-93 for coarse aggregates and ASTM C 128-97 for fine aggregates. The results are as shown in Table 1.
TABLE 1 . Specific gravity of materials

\begin{tabular}{cc}
\hline Sieve size $(\mathrm{mm})$ & $\begin{array}{c}\text { Specific } \\
\text { gravity, } \mathrm{G}_{\mathrm{sg}}\end{array}$ \\
\hline 9.50 & 2.63 \\
4.75 & 2.63 \\
2.36 & 2.64 \\
0.30 & 2.65 \\
0.075 & 2.64 \\
Pan & 2.65 \\
$4.75 \mathrm{~mm}$ (Palm oil shells) & 1.16 \\
$4.75 \mathrm{~mm}$ (Coconut shells) & 0.94 \\
Asphalt cement & 1.03 \\
\hline
\end{tabular}

Five replicates of blends had been prepared for each mix type (POS, CS and controls) by diversifying the percentage of POS and CS added. The 80/100 asphalt was used in this research. Two specimens were prepared for each asphalt contents ranged from 4 to $6 \%$ and 125 gyrations were applied to each specimen. Having prepared the samples, the volumetric properties namely the voids in the mineral aggregate (VMA), voids in the total mix (Va) and voids filled with asphalt (VFA) were computed to determine the optimum asphalt content (OAC).

According to the results that have been given, the OAC was determined at $4 \%$ air voids as referred to the National Asphalt Pavement Association (NAPA). The OAC values increased as the percentage of the POS being added increased, also they decreased as the percentage of the CS added increased. This could be due to the reaction, absorption of asphalt, between the asphalt and POS and CS. For this OAC, it was discovered that most volumetric properties have met the specifications required except for the result of $20 \%$ POS, $15 \%$ and $20 \%$ CS. The determination of OAC was included as shown in Tables 2 and 3.

TABLE 2. Optimum asphalt content for POS mixes

\begin{tabular}{lccccc}
\hline \multicolumn{5}{c}{ Asphalt content \% } \\
\hline Percentage of agg. size $4.75 \mathrm{~mm}$ & $0 \%$ & $5 \%$ & $10 \%$ & $15 \%$ & $20 \%$ \\
Resilient modulus (MPa) & 4.70 & 4.80 & 5.35 & 5.25 & 5.30 \\
VMA (\%) & 4.50 & 4.80 & 5.40 & 5.65 & 5.70 \\
Va $(\%)$ & 5.80 & 5.85 & 5.80 & 5.35 & 5.45 \\
U.W $\left(\mathrm{g} / \mathrm{cm}^{3}\right)$ & 5.00 & 5.14 & 5.40 & 5.79 & 5.80 \\
VFA $(\%)$ & 5.05 & 5.16 & 5.49 & 5.52 & 5.55 \\
OAC & 5.00 & 5.15 & 5.49 & 5.51 & 5.56 \\
\hline
\end{tabular}


TABLE 3. Optimum asphalt content for CS mixes

\begin{tabular}{lccccc}
\hline \multicolumn{5}{c}{ Asphalt content \% } \\
\hline Percentage of agg. size 4.75 mm & $0 \%$ & $5 \%$ & $10 \%$ & $15 \%$ & $20 \%$ \\
Resilient modulus (Mpa) & 4.70 & 4.90 & 4.85 & 4.75 & 4.65 \\
VMA (\%) & 4.50 & 5.55 & 5.35 & 5.55 & 5.50 \\
Va (\%) & 5.80 & 5.80 & 5.60 & 5.05 & 5.10 \\
U.W $\left(\mathrm{g} / \mathrm{cm}^{3}\right)$ & 5.00 & 5.70 & 5.45 & 5.75 & 5.70 \\
VFA (\%) & 5.05 & 5.48 & 5.29 & 5.30 & 5.23 \\
OAC & 5.00 & 5.49 & 5.31 & 5.28 & 5.24 \\
\hline
\end{tabular}

\section{VOLUMETRIC PROPERTIES}

Based on the results, the link between the volumetric properties, bitumen and POS and CS content had been evaluated. Then the OAC for POS and CS contents that work prominently in improving the HMA mixes were determined. The results of confirmed samples were recorded as shown in Tables 4 and 5 for both designs of the mixes with the addition of different contents of POS and CS.

TABLE 4. Results of the mixes modified with POS

\begin{tabular}{lcccccc}
\hline & \multicolumn{3}{c}{ Palm oil shell* } & \multicolumn{1}{c}{ Specifications } \\
\cline { 2 - 5 } & $0 \%$ & $5 \%$ & $10 \%$ & $15 \%$ & $20 \%$ & \\
\hline O.A.C & 5 & 5.15 & 5.49 & 5.51 & 5.56 \\
Resilient modulus (MPa) & 351 & 480 & 457 & 434 & 390 & Min. $=13$ \\
VMA (\%) & 16.12 & 15.37 & 15.06 & 14.53 & 13.84 & $3-5$ \\
Va (\%) & 4.43 & 4.14 & 3.2 & 2.73 & 2.01 & $65-75$ \\
VFA $(\%)$ & 69.5 & 73.09 & 78.73 & 81.23 & 85.47 & 2.261 \\
U.W $\left(\mathrm{gm} / \mathrm{cm}^{3}\right)$ & 2.25 & 2.315 & 2.296 & 2.276 & & \\
\hline
\end{tabular}

*all percentages are of size $4.75 \mathrm{~mm}$ aggregate.

TABLE 5. Results of the mixes modified with CS

\begin{tabular}{lcccccc}
\hline & \multicolumn{7}{c}{ Coconut shell* } \\
\cline { 2 - 6 } & $0 \%$ & $5 \%$ & $10 \%$ & $15 \%$ & $20 \%$ & Specification \\
\hline O.A.C & 5 & 5.49 & 5.31 & 5.28 & 5.24 \\
Resilient modulus (MPa) & 351 & 405 & 447 & 510 & 526 & Min. $=13$ \\
VMA (\%) & 16.12 & 16.10 & 15.17 & 14.86 & 14.08 & $3-5 \%$ \\
Va (\%) & 4.43 & 4.28 & 3.87 & 3.82 & 3.24 & $65-75$ \\
VFA (\%) & 69.50 & 73.42 & 74.51 & 74.30 & 76.97 & 2.192 \\
U.W $\left(\mathrm{gm} / \mathrm{cm}^{3}\right)$ & 2.250 & 2.288 & 2.260 & 2.219 & & \\
\hline
\end{tabular}

*all percentages are of size $4.75 \mathrm{~mm}$ aggregate. 
INDIRECT TENSILE MODULUS TEST

The resilient modulus is a variable most significant in the mechanistic design of pavement structures. It is the measure of pavement response in light of its dynamic stresses and corresponding strains. Three samples from POS, CS content and controls (for OAC) were tested under the diametric resilient modulus test at temperature of $40^{\circ} \mathrm{C}$. Figure 2 shows the results in summary to compare between the three- POS, CS and control mixes. For the POS mixes, the resilient modulus was found to be $480 \mathrm{MPa}$; this value reduced to $390 \mathrm{MPa}$ (from 5 to $20 \%$ of POS). For CS mixes, the resilient modulus increased from $405 \mathrm{MPa}$ CS mixes to $526 \mathrm{MPa}$ (from 5 to $20 \%$ of CS) as shown in Figure 2. For the 5 and $10 \%$, of the CS mixes, the resilient modulus values are lower than it is in the POS mixes for the same percentages of shells. The improvement of resilient modulus in CS mixes is not significant but at least now it is clear that the study can continue using cured CS or with changing the additive size.

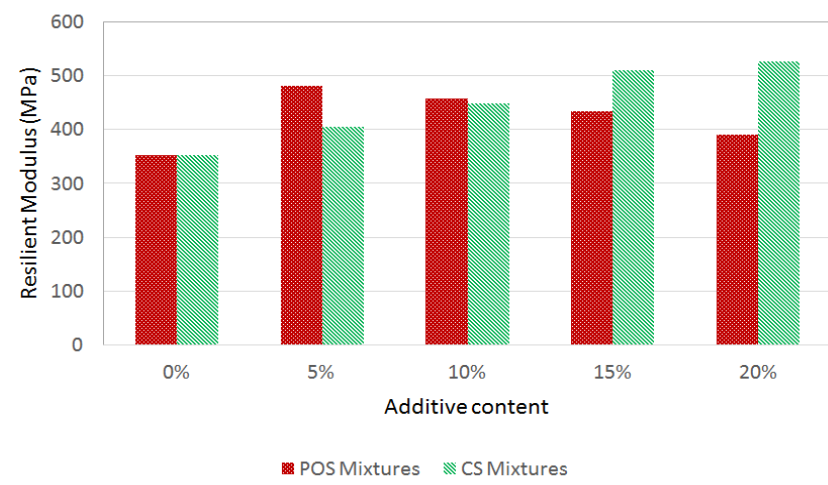

FIGURE2. Comparing the resilient modulus results for POS, CS and control mixes

\section{STATIC CREEP TEST}

The static creep test is run by having a static load imposed onto a specimen (OAC) and then the deformation of the specimen measured after the unloading is done. It is the intention of the test to delve into the asphalt mixtures' permanent deformation. This characteristic of the asphalt mixtures was believed to have something to do with the rutting potential. Creep deformation of a cylindrical specimen under an axial static load was evaluated as a time function, and both the sample dimensions and test conditions were made consistent. The values of the static creep compliance gained from the test are shown in Figures 3 and 4 (for POS, CS and control samples). In general, the strains of the asphalt concrete mixtures at first had increased swiftly, but became steady later in a test that went on for an hour. Following the static creep results, the $5 \%$ of the POS mixture revealed higher performance than the other POS mixes, and also 5\% of CS mixes showed equally higher performance than the other CS and control mixes. However, the CS mixtures have more credible performance than POS mixtures.

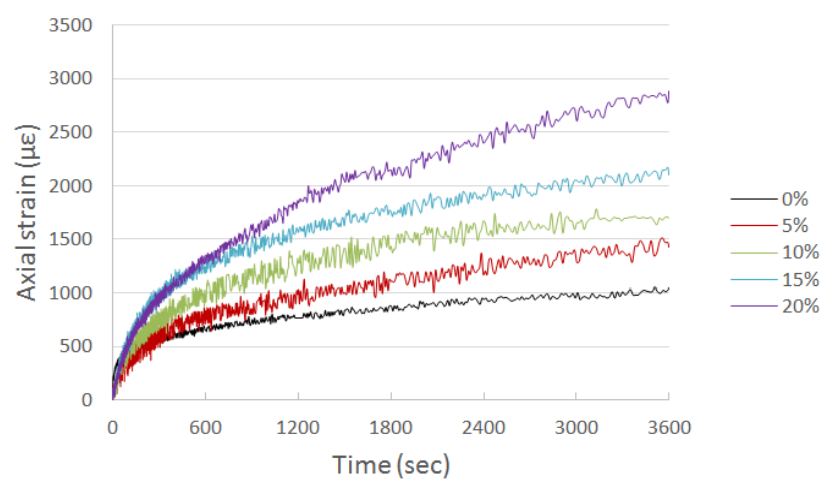

FIGURE 3. Comparison of static creep behaviour between POS mixes

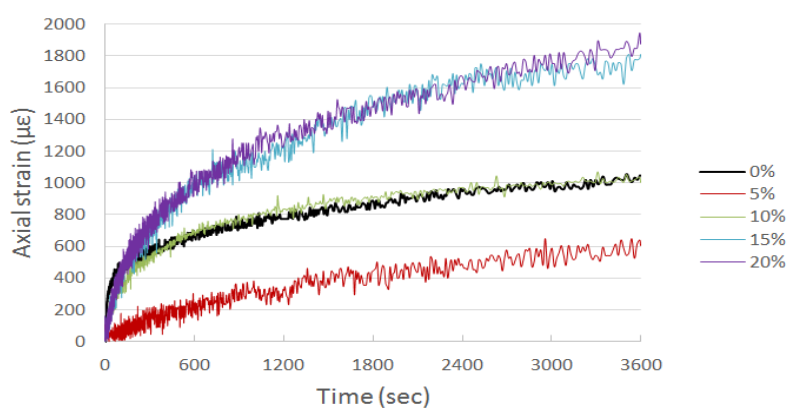

FIGURE 4. Comparison of static creep behaviour between CS mixes

\section{DYNAMIC CREEP TEST}

The robustness of the bituminous mixtures to plastic deformation is verifiable based on the dynamic creep test. The test equipment does not differ at all from the static creep test, but the test's repetitious load portion is done in a different manner. Table 6 shows the maximum permanent deformation for POS, CS and control mixes in the dynamic creep test. 
TABLE 6. Comparison between POS mix and CS mix in dynamic creep behaviour

\begin{tabular}{ccc}
\hline Percentage of additives (\%) & \multicolumn{2}{c}{ Maximum permanent deformation (mm) } \\
\hline 0 & POS & 0.247655 \\
5 & 0.247655 & 0.101954 \\
10 & 0.128984 & 0.399878 \\
15 & 0.453671 & 0.496093 \\
20 & 0.564764 & 0.641636 \\
\hline
\end{tabular}

Adding shells to the asphalt have enabled the effects or specifically the negative effects on the theological behaviour (i.e., a decrease in stiffness) to show the fact that the added shells has caused the asphalt concrete to become more sensitive to permanent deformation when the percentages are more than 5\% for both POS and CS. This is reasoned by some instability issues forming from the physical reaction between shells and the asphalt mixtures. The POS and CS lower the improvement of the creep resistance as the cohesive and plastic properties of the asphalt mixtures are lost. The addition of POS and CS also does not significantly improve the modified asphalt concrete performance as also found by Do Vale et al. 2013 on the study of coconut fibre in Stone Mastic Asphalt (SMA). However, the samples modified with CS show better creep resistance than the samples that have been adapted to the POS.

\section{CONCLUSIONS}

According to the results of the experimental investigations on the creeping performance on the modified mixes for both types of shells, the following conclusions were derived.

1. Adding of POS does not improve the diametral resilient modulus of the modified mixes, but adding of CS improves the diametral resilient modulus of the modified mixes;

2. Adding $5 \%$ of shell has improved the mixture against dynamic creep;

3. POS and CS more than $5 \%$ contents of addition, have made the asphalt concrete more receptive to permanent deformation. The POS and CS lower the chance of improvement of the creep resistance following the decreased the cohesive and plastic properties of the asphalt mixtures; and

4. In general, coconut shell showed better performance as additives with hot mix of asphalt compared to the palm oil shell.
ACKNOWLEDGMENT

The authors would like to acknowledge the Sustainable Urban Transport Research Centre (SUTRA) and Universiti Kebangsaan Malaysia (UKM) for providing research facilities.

\section{REFERENCES}

AASHTO. 1994. A Policy on Geometric Design of Highways and Streets. American Association of State Highway and Transportation Officials.

Asi, I.M. 2007. Performance evaluation of Superpave and Marshall asphalt mix designs to suite Jordan climatic and traffic conditions. Construction and Building Materials 21(8): 1732-40.

ASTM International. 1990. Annual Book of ASTM Standards. $3^{\text {rd }}$ edition. American Society for Testing and Materials.

ASTM. 1996. Standard specification for hot-mixed, hotlaid bituminous paving mixtures. American Society for Testing and Materials D 3515. Conshohocken, Pennsylvania.

ASTM. 2000. Standard test method for theoretical maximum specific gravity and density of bituminous paving mixtures. American Society for Testing and Materials D 2041. Conshohocken, Pennsylvania.

ASTM.2003a. Standard test method for density, relative density (specific gravity) and absorption of coarse aggregate. American Society for Testing and Materials C 127. Conshohocken, Pennsylvania.

ASTM. 2003b. Test method for density, relative density (specific gravity), and absorption of fine aggregate. American Society for Testing and Materials C 128. Conshohocken, Pennsylvania.

ASTM. 2010. Standard test method for bulk specific gravity and density of non-absorptive compacted bituminous mixtures. American Society for Testing and Materials D 2726. Conshohocken, Pennsylvania.

Basri, H. B., Mannan, M. A. \&Zain, M. F. M. 1999. Concrete using waste oil palm shells as aggregate. Cement and Concrete Research 29(4): 619-22. 
Chandramohan, K. K. M. D. 2002.Malaysian palm oil industry at crossroads and its future direction.Oil Palm Industry Economic Journal 12(2): 1-6.

Chen, Z., Li, H. \& Wong, C. T. C. 2002. An application of bar-code system for reducing construction wastes. Journal of Automat Construct 11(5): 521-33.

Do Vale, M.,Casagrande, J. \&Soares 2013. A study of behaviour of natural fibre in stone matrix asphalt using two design methods. Journal Material Civil Engineering 10: 1061.

FAOSTAT. 2011. Food and Agriculture Organization of the United Nations. http://www.fao.org/statistics.

Ferguson, J., Kermode, N., Nash, C.L., Sketch, W.A.J., \&Huxford, R.P. 1995. Managing and Minimizing Construction Waste: A Practical Guide. London: London Institute of Civil Engineers.

Fishbein, B. K. 2008. Building for the future: strategies to reduce construction and demolition waste in municipal projects. http://www.informinc.org/cdreport.

Huang, Y., Bird, R. N. \& Heidrich, O. 2007.A review of the use of recycled solid waste materials in asphalt pavements. Resources, Conservation and Recycling 52(1): 58-73.

Laili, S.N. 2009. Using of palm oil shells as a modifier with hot mix of asphalt. Universiti Kebangsaan Malaysia: Master dissertation (unpublished).

Mannan, M,A., Alexander, J., Ganapathy, C., \&Teo, D.C.L. 2006.Quality improvement of oil palm shell (OPS) as coarse aggregate in lightweight concrete. Building and Environment 41(9): 1239-42.

Memon, N.A. 2006. Comparison Between Superpave Gyratory and Marshall Laboratory Compaction Methods.Skudai:Universiti Technology of Malaysia.

Muniandy, R. \& Huat, B.B.K. 2006.Laboratory diametral fatigue performance of stone matrix asphalt with cellulose oil palm fiber. Am J Appl Sci.3 (9): 2005 2010.

Kordi, N. E., Endut, I. R. \&Baharom, B. 2010.Types of damages on flexible pavement for Malaysian federal road. Proceeding of Malaysian universities transportation research forum and conferences (MUTRFC2010) 421-432.

Olanipekun, E. A., Olusola, K. O. \& Ata, O. 2006.A comparative study of concrete properties using coconut shell and palm kernel shell as coarse aggregates. Building and Environment 41(3): 297-301.

Pakiam, R. 2013. Palm Oil Advances as Malaysia's Export Tax May Boost Shipments. Kuala Lumpur: Bloomberg.

Shafigh, P., Jumaat M.Z., \& Mahmud, H. 2011.Oil palm shell as a lightweight aggregate for production high strength lightweight concrete. Construction and Building Materials 25(4): 1848-53.
Shean, M., 2012.Stagnating Palm Oil Yields Impede Growth. USA: United States Department of Agriculture.

Shen, L.Y., Tam, V.W.Y., Tam, C.M. \&Ho, S. 2000. Material wastage in construction activities - A Hong Kong survey. Proceeding of the first CIB-W107 International Conference - Creating a Sustainable Construction Industry in Developing Countries, 125-31.

Smallwood, J. J. 2000.Construction and the environmentgeneral contractor (GC) perceptions and practices. Proc. of the first CIB-W107 International Conference: Creating a Sustainable Construction Industry in Developing Countries, 155-64.

Teo, D. C. L., Mannan, M. A. \& Kurian, V. J. 2006. Structural concrete using oil palm shell (OPS) as lightweight aggregate. Turkish Journal Engineering Environment Science 30: 1-7.

Teo, D. C. L., Mannan, M. A., Kurian, V. J., Ganapathy, C. 2007. Lightweight concrete made from oil palm shell (OPS): Structural bond and durability properties. Building and Environment 42(7): 2614-21.

Vitidsant, T., Suravattanasakul, T., Damronglerd, S. 1999. Production of activated carbon from palm-oil shell by pyrolysis and steam activation in a fixed bed reactor. Science Asia Journal 25: 211-22.

Ramez A. Al-Mansob, Amiruddin Ismail, Mohammad Hesam Hafezi \& Mojtaba Shojaei Baghini Sustainable Urban Transport Research Centre (SUTRA) / Department of Civil and Structural Engineering, Faculty of Engineering and Built Environment, Universiti Kebangsaan Malaysia 43600 Selangor, Malaysia.

Mohammed A. Algorafi, Department of Civil Engineering Sanaa University

Harat Bi'r Ash Shaif

Sana'a, Yemen

*Corresponding author; email: ramizizzi@gmail.com

Received: 20 April 2013

Accepted: 18 Februari 2014 
